\title{
Geochemical studies of surface bottom sediments and soils of small watercourses
}

\author{
Evgeni Nesterov*, Timofei Belyakov, Stanislav Dubrova, and Pavel Egorov \\ Herzen State Pedagogical University of Russia, Geology and Geoecology Department, 198328 \\ Saint Petersburg, Russian Federation
}

\begin{abstract}
Analytical data on samples of bottom sediments of the Novaya river watercourse made it possible to identify areas of pollution, sources of pollution and determine the nature of the influence of the anthropogenic factor on the state of the river. It was found that bottom sediments are divided into slightly polluted, moderately polluted, and dangerously polluted. Soils on the total indicator of pollution belong to the permissible category. The list of defined indicators includes: hydrogen index $(\mathrm{pH})$, total metal content (cadmium, copper, lead, mercury, nickel, zinc), arsenic, petroleum products, benz(a)pyrene, ammonium nitrogen, phosphate ion, organic matter. Based on the results of the interpretation of the laboratory data, it was found that in accordance with the Regional standard, the precipitation the majority of samples are slightly polluted; at some samples, are moderately polluted; at a quarter of samples are dangerously polluted.
\end{abstract}

\section{Introduction}

Geochemical studies of surface bottom sediments were carried out on various sections of the small watercourse (the Novaya river, Saint Petersburg) and included determination of the content of organic matter (according to the LOI), phosphorus, nitrogen, macro-and microelements [2].

In the course of the work, an assessment of the general chemical contamination and sanitary condition of bottom sediments was made. The geoecological testing of bottom sediments was carried out in four stages during the calendar year. The quantitative chemical analysis of bottom sediments was carried out according to the certified measurement methods in the Test center of TACIS LLC.

The list of defined indicators includes: hydrogen index $(\mathrm{pH})$, total metal content (cadmium, copper, lead, mercury, nickel, zinc), arsenic, petroleum products, benz(a)pyrene, ammonium nitrogen, phosphate ion, organic matter. Macroelements are those containing more than $0.01 \%$, and microelements - from $10-6$ to $0.01 \%$. Macroelements include copper, lead, zinc, nickel, and microelements - cadmium, arsenic.

The heavy metals selected for the analysis are identified as priority pollutants for the Novaya river (Fig. 1).

\footnotetext{
*Corresponding author: nestem26@mail.ru
} 


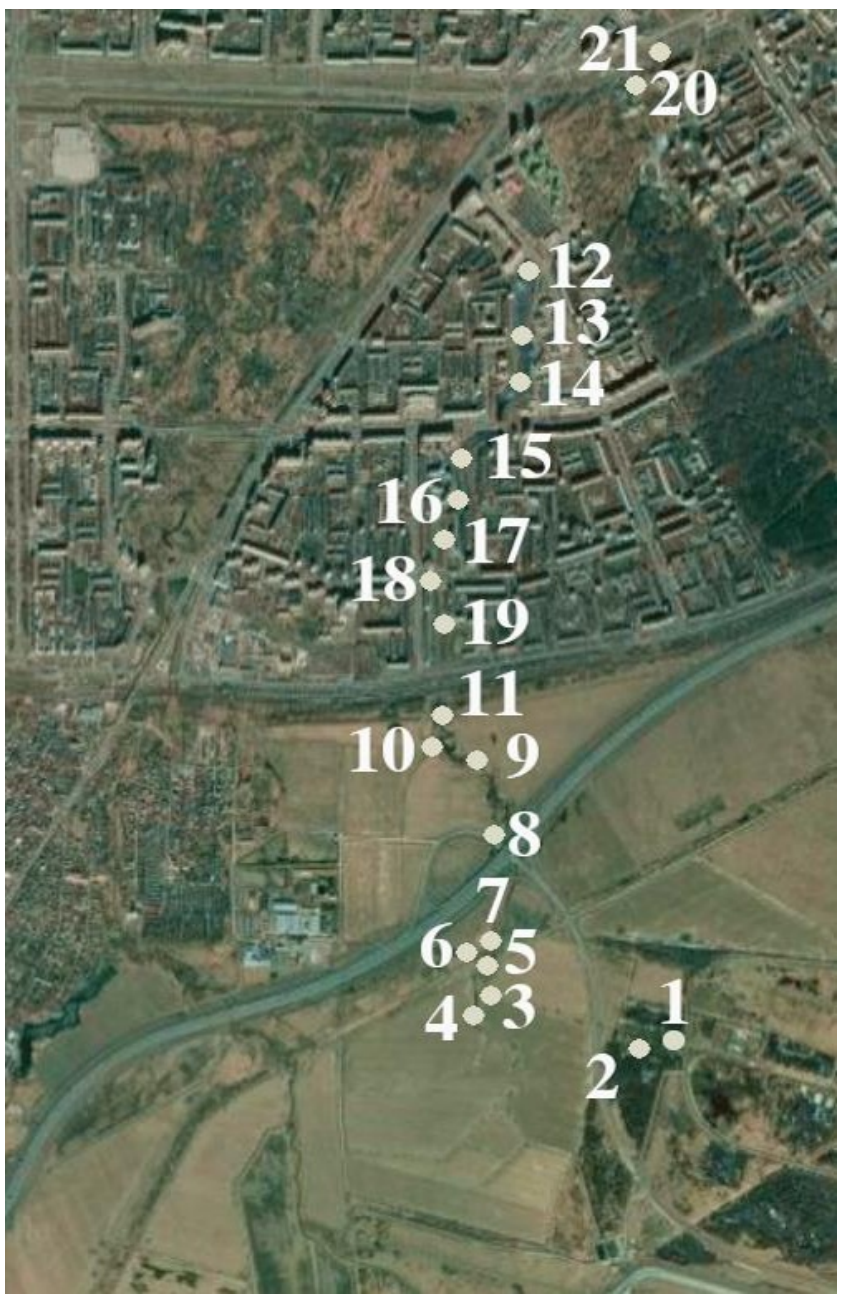

Fig. 1. The scheme of sampling

The degree of contamination of bottom sediments was assessed using standardized values of the contents of pollutants in accordance with the recommendations of the normative document: «The norms and criteria for assessing the pollution of bottom sediments in water objects of St. Petersburg. The regional standard». The composition of standard sediments: $10 \%$ of the organic matter content and $25 \%$ of the clay fraction. The concentrations of pollutants in non-standard bottom sediments were recalculated by their concentrations in standard bottom sediments [3-4, 6-7].

\section{Research materials and methods}

In accordance with the established Regional standard classifier, the bottom sediments of the water objects of St. Petersburg are divided into 4 levels and V classes. The target level: if the concentration of pollutants is below the target level, the bottom sediments are considered clean. These sediments belong to class 0 . The limit level: the concentrations of pollutants up to this level represent the maximum acceptable risk for both human health and nature. Bottom sediments with concentrations of pollutants between the target and limit levels belong to class I. These sediments are considered to be slightly polluted. The control 
level: under certain conditions, pollutants in sediments with concentrations below this level can have a negative impact on the clean water environment. Bottom sediments with a concentration of pollutants between the limit and control levels belong to class II. They are considered to be moderately polluted. The level requiring intervention: if the concentration of pollutants exceeds the class II control level, it is considered an indicator of hard pollution of bottom sediments. Bottom sediments with a concentration of pollutants between the control level and the level requiring intervention belong to class III. The pollution of these sediments is considered to be moderate to hard. Bottom sediments where the concentration of pollutants exceeds the level that requires intervention are considered to be dangerously polluted. They belong to class IV.

\subsection{Ecochemical characteristics of bottom sediments}

The results of the interpretation of the laboratory data showed that in accordance with the Regional standard, the precipitation samples collected at stations $9,10,11,13,14,15,16,17$ are slightly polluted; 4, 5, 18 - moderately polluted; 1, 12, 19, 20, 21 - dangerously polluted (Table 1).

Table 1. Nitrogen and phosphorus in the Novaya river basin

\begin{tabular}{|c|c|c|c|c|c|c|c|c|c|}
\hline \multirow{2}{*}{$\begin{array}{l}\mathrm{Nr} \\
\cdot\end{array}$} & \multirow{2}{*}{$\begin{array}{c}\text { May } 2019 \\
\text { P total }\end{array}$} & \multicolumn{2}{|c|}{ May 2019} & \multicolumn{3}{|c|}{ July 2019} & \multicolumn{3}{|c|}{ October 2019} \\
\hline & & $N$ total & N amm. & P total & $N$ total & $\begin{array}{c}\mathbf{N} \\
\mathbf{a m m} .\end{array}$ & $P$ total & $\mathrm{N}$ total & $\begin{array}{c}\mathrm{N} \\
\text { amm. }\end{array}$ \\
\hline 1 & 0.042 & $\begin{array}{c}11.0(\mathrm{~s})^{* * *} \\
11.0(\mathrm{~b})\end{array}$ & $\begin{array}{l}8.4(\mathrm{~s}) \\
8.2(\mathrm{~b})\end{array}$ & 0.11 & 25.0 & 22.0 & - & - & - \\
\hline 2 & 0.015 & 5.1 & 3.8 & 0.14 & 18.0 & 15.0 & - & - & - \\
\hline 3 & 0.047 & 9.2 & 7.3 & 0.09 & 12.0 & 7.8 & - & - & - \\
\hline 4 & 0.060 & 12.0 & 8.1 & 0.14 & 12.0 & 9.3 & 5.1 & 26 & 18.1 \\
\hline 5 & 0.033 & 10.2 & 7.0 & 0.14 & 11.0 & 8.6 & - & - & - \\
\hline 6 & 0.070 & 5.4 & 3.7 & 0.18 & 17.0 & 8.5 & - & - & - \\
\hline 7 & - & 7.1 & 6.6 & - & - & - & 0.016 & 4.0 & 3.2 \\
\hline 8 & 0.130 & 9.8 & 7.5 & 0.040 & 16.0 & 7.6 & 0.25 & 6.6 & 5.3 \\
\hline 9 & 0.030 & 11.0 & 6.7 & 0.28 & 23.0 & 12.0 & 0.66 & 13 & 10.4 \\
\hline 10 & 1.200 & 9.2 & 6.9 & 5.50 & 41.0 & 31.0 & 3.0 & 31 & 24.0 \\
\hline 11 & 0.070 & 12.0 & 7.8 & 0.35 & 25.0 & 13.0 & 0.55 & 18 & 15.2 \\
\hline 12 & 0.100 & $\begin{array}{l}7.0(\mathrm{~s}) \\
8.3(\mathrm{~b})\end{array}$ & $\begin{array}{l}4.6(\mathrm{~s}) \\
6.1(\mathrm{~b})\end{array}$ & $\begin{array}{l}0.15(\mathrm{~s}) \\
0.16(\mathrm{~b})\end{array}$ & $\begin{array}{l}19.0(\mathrm{~s}) \\
12.0(\mathrm{~b})\end{array}$ & $\begin{array}{l}12.0(\mathrm{~s}) \\
9.7(\mathrm{~b})\end{array}$ & 0.31 & 21 & 17.2 \\
\hline 13 & 0.070 & $\begin{array}{l}7.2(\mathrm{~s}) \\
8.4(\mathrm{~b})\end{array}$ & $\begin{array}{l}5.6(\mathrm{~s}) \\
6.3(\mathrm{~b})\end{array}$ & $\begin{array}{l}0.23(\mathrm{~s}) \\
0.09 \text { (b) }\end{array}$ & $\begin{array}{l}15.0(\mathrm{~s}) \\
13.7 \text { (b) }\end{array}$ & $\begin{array}{l}11.0(\mathrm{~s}) \\
7.5(\mathrm{~b})\end{array}$ & 0.26 & 21 & 17.7 \\
\hline 14 & $\begin{array}{l}0.080(\mathrm{~s}) \\
0.240(\mathrm{~b})\end{array}$ & $\begin{array}{l}8.1(\mathrm{~s}) \\
8.5(\mathrm{~b})\end{array}$ & $\begin{array}{l}5.9(\mathrm{~s}) \\
6.9(\mathrm{~b})\end{array}$ & $\begin{array}{l}0.08 \text { (s) } \\
0.10 \text { (b) }\end{array}$ & $\begin{array}{l}13.0(\mathrm{~s}) \\
13.0(\mathrm{~b})\end{array}$ & $\begin{array}{l}7.4(\mathrm{~s}) \\
6.8(\mathrm{~b})\end{array}$ & $\begin{array}{l}0.27 \text { (s) } \\
0.26 \text { (b) }\end{array}$ & $\begin{array}{l}22(\mathrm{~s}) \\
22(\mathrm{~b})\end{array}$ & $\begin{array}{l}19.0(\mathrm{~s}) \\
17.9(\mathrm{~b})\end{array}$ \\
\hline 15 & 0.110 & $\begin{array}{l}7.7(\mathrm{~s}) \\
9.4(\mathrm{~b})\end{array}$ & $\begin{array}{l}6,9(\mathrm{~s}) \\
7.6(\mathrm{~b})\end{array}$ & $\begin{array}{l}0.25(\mathrm{~s}) \\
0.33(\mathrm{~b})\end{array}$ & $\begin{array}{l}61.0(\mathrm{~s}) \\
18.0(\mathrm{~b})\end{array}$ & $\begin{array}{c}20.0(\mathrm{~s}) \\
7.2(\mathrm{~b})\end{array}$ & $<0.10$ & 24 & 20.0 \\
\hline 16 & $\begin{array}{l}0.160(\mathrm{~s}) \\
0.060(\mathrm{~b})\end{array}$ & - & - & $\begin{array}{l}0.31(\mathrm{~s}) \\
0.28(\mathrm{~b})\end{array}$ & $\begin{array}{l}22.0(\mathrm{~s}) \\
24.0(\mathrm{~b})\end{array}$ & $\begin{array}{c}8.6(\mathrm{~s}) \\
11.0(\mathrm{~b})\end{array}$ & $\begin{array}{c}0.08 \text { (s) } \\
<0.10 \text { (b) }\end{array}$ & $\begin{array}{l}24(\mathrm{~s}) \\
25(\mathrm{~b})\end{array}$ & $\begin{array}{l}19.7 \\
21.0\end{array}$ \\
\hline 17 & $\begin{array}{l}0.050(\mathrm{~s}) \\
0.080(\mathrm{~b})\end{array}$ & $\begin{array}{l}9.7(\mathrm{~s}) \\
9.2(\mathrm{~b})\end{array}$ & $\begin{array}{l}7.7(\mathrm{~s}) \\
7.9(\mathrm{~b})\end{array}$ & $\begin{array}{l}0.22(\mathrm{~s}) \\
0.10(\mathrm{~b})\end{array}$ & $\begin{array}{l}16.0(\mathrm{~s}) \\
24.0(\mathrm{~b})\end{array}$ & $\begin{array}{l}7.2(\mathrm{~s}) \\
7.2(\mathrm{~b})\end{array}$ & $\begin{array}{l}<0.10 \text { (s) } \\
<0.10 \text { (b) }\end{array}$ & $\begin{array}{l}27 \text { (s) } \\
27 \text { (b) }\end{array}$ & $\begin{array}{l}22.0(\mathrm{~s}) \\
22.9(\mathrm{~b})\end{array}$ \\
\hline 18 & $\begin{array}{l}0.080(\mathrm{~s}) \\
0.170(\mathrm{~b})\end{array}$ & $\begin{array}{l}8.2(\mathrm{~s}) \\
8.0(\mathrm{~b})\end{array}$ & $\begin{array}{l}6.0(\mathrm{~s}) \\
6.3(\mathrm{~b})\end{array}$ & $\begin{array}{l}0.09(\mathrm{~s}) \\
0.12(\mathrm{~b})\end{array}$ & $\begin{array}{l}18.0(\mathrm{~s}) \\
18.0(\mathrm{~b})\end{array}$ & $\begin{array}{l}10.0(\mathrm{~s}) \\
11.0(\mathrm{~b})\end{array}$ & $\begin{array}{l}<0.10 \text { (s) } \\
<0.10 \text { (b) }\end{array}$ & $\begin{array}{l}24(\mathrm{~s}) \\
24(\mathrm{~b})\end{array}$ & $\begin{array}{l}19.4(\mathrm{~s}) \\
19.7(\mathrm{~b})\end{array}$ \\
\hline 19 & $\begin{array}{l}0.060(\mathrm{~s}) \\
0.090(\mathrm{~b})\end{array}$ & $\begin{array}{c}8.8(\mathrm{~s}) \\
10.2(\mathrm{~b})\end{array}$ & $\begin{array}{l}7.1(\mathrm{~s}) \\
8.7(\mathrm{~b})\end{array}$ & $\begin{array}{c}0.09(\mathrm{~s}) \\
0.051(\mathrm{~b})\end{array}$ & $\begin{array}{l}14.0(\mathrm{~s}) \\
26.0(\mathrm{~b})\end{array}$ & $\begin{array}{l}13.7(\mathrm{~s}) \\
20.0(\mathrm{~b})\end{array}$ & $\begin{array}{l}0.18 \text { (s) } \\
0.18 \text { (b) }\end{array}$ & $\begin{array}{l}22(\mathrm{~s}) \\
22(\mathrm{~b})\end{array}$ & $\begin{array}{l}18.3(\mathrm{~s}) \\
18.0(\mathrm{~b})\end{array}$ \\
\hline 20 & 0.460 & $<1.0$ & 0.39 & 0.31 & 3.0 & 0.18 & 0.54 & 1,4 & 0.93 \\
\hline 21 & $\begin{array}{l}0.220(\mathrm{~s}) \\
1.500(\mathrm{~b})\end{array}$ & $<1.0$ & $\begin{array}{l}0.31(\mathrm{~s}) \\
0.35(\mathrm{~b})\end{array}$ & $\begin{array}{l}0.30 \text { (s) } \\
0.33 \text { (b) }\end{array}$ & $\begin{array}{l}13.0(\mathrm{~s}) \\
12.0(\mathrm{~b})\end{array}$ & $\begin{array}{l}0.18 \text { (s) } \\
0.15 \text { (b) }\end{array}$ & $\begin{array}{l}0.56 \text { (s) } \\
0.51 \text { (b) }\end{array}$ & $\begin{array}{l}<1(\mathrm{~s}) \\
<1(\mathrm{~b})\end{array}$ & $\begin{array}{l}0.57 \\
0.56\end{array}$ \\
\hline
\end{tabular}

* in October, releases 1 and 2 - tamponaded, channel 6 - dry.

$* *(\mathrm{~s})$ - surface ; (b) - bottom. 
In order to obtain more objective information, the selection was made at different agreed stations. So, the samples were taken at station 7 in May and October, and at station 16 - in July and October.

Ecological condition of soils in the water catchment area

To study the sources of pollution of the Novaya river and to calculate the diffuse biogenic load, we conducted an assessment of soil pollution in the catchment area. Soil sampling is performed in accordance with the State standarts GOST 17.4.4.02-84.

\subsection{Methods of soil research}

The soil pollution was estimated by the gross content of metals (vanadium, chromium, cobalt, nickel, copper, zinc, lead) and arsenic [6]. The determination of the network of testing stations and sampling was carried out in accordance with the recommendations set out in the articles 4.19 and 6.17 of SR (Sanitary Regulations) 11-102-97. The data provided in SR 11-102-97 were used to assess the background state of soils and grounds (Table 2). The assessment of the degree of soil pollution was carried out by comparing the measured values of the content of pollutants with the standards established by HS (hygienic standard) 2.1.7.2041-06 (MPC of chemicals in the soil) and HS 2.1.7.2511-09 (TAC of chemicals in the soil), as well as by the indicator [5].

Table 2. Assessment of the degree of chemical pollution of soils (according to Sanitary Regulations and Norms 2.1.7.1287-03)

\begin{tabular}{|c|c|c|c|c|c|c|c|}
\hline \multirow{3}{*}{$\begin{array}{l}\text { Pollution } \\
\text { categories }\end{array}$} & \multirow{3}{*}{\begin{tabular}{|c|}
$\sum_{\text {pollution }}$ \\
Indic. \\
$(\mathrm{Zc})$ \\
\end{tabular}} & \multicolumn{6}{|c|}{ Soil content $(\mathrm{mg} / \mathrm{kg})$} \\
\hline & & \multicolumn{2}{|c|}{ I danger class } & \multicolumn{2}{|c|}{ II danger class } & \multicolumn{2}{|c|}{ III danger class } \\
\hline & & $\begin{array}{c}\text { Organic } \\
\text { compounds }\end{array}$ & $\begin{array}{c}\text { Inorganic } \\
\text { compounds }\end{array}$ & $\begin{array}{c}\text { Organic } \\
\text { compounds }\end{array}$ & \begin{tabular}{|c|} 
Inorganic \\
compounds
\end{tabular} & $\begin{array}{c}\text { Organic } \\
\text { compounds }\end{array}$ & $\begin{array}{l}\text { Inorganic } \\
\text { compounds }\end{array}$ \\
\hline Clean & - & $\begin{array}{c}\text { from } \\
\text { background } \\
\text { to MPC }\end{array}$ & $\begin{array}{c}\text { from } \\
\text { background } \\
\text { to MPC }\end{array}$ & $\begin{array}{c}\text { from } \\
\text { background } \\
\text { to MPC }\end{array}$ & $\begin{array}{c}\text { from } \\
\text { background } \\
\text { to MPC }\end{array}$ & $\begin{array}{c}\text { from } \\
\text { background } \\
\text { to MPC }\end{array}$ & $\begin{array}{c}\text { from } \\
\text { background } \\
\text { to MPC }\end{array}$ \\
\hline Permissible & $<16$ & $\begin{array}{l}\text { from } 1 \text { to } 2 \\
\text { MPC }\end{array}$ & $\begin{array}{c}\text { from } 2 \\
\text { backgr. } \\
\text { values } \\
\text { to MPC }\end{array}$ & $\begin{array}{c}\text { from } 1 \text { to } 2 \\
\text { MPC }\end{array}$ & $\begin{array}{c}\text { from } 2 \\
\text { backgr. } \\
\text { values } \\
\text { to MPC }\end{array}$ & $\begin{array}{l}\text { from } 1 \text { to } 2 \\
\text { MPC }\end{array}$ & $\begin{array}{c}\text { from } 2 \\
\text { backgr. } \\
\text { values } \\
\text { to MPC }\end{array}$ \\
\hline $\begin{array}{c}\text { Moderately } \\
\text { dangerous }\end{array}$ & $16-32$ & & & & & $\begin{array}{c}\text { from } 2 \text { to } 5 \\
\text { MPC }\end{array}$ & $\begin{array}{c}\text { from MPC } \\
\text { to Cmax }\end{array}$ \\
\hline Dangerous & $32-128$ & $\begin{array}{c}\text { from } 2 \text { to } 5 \\
\text { MPC }\end{array}$ & $\begin{array}{c}\text { from MPC to } \\
\text { Cmax }\end{array}$ & $\begin{array}{c}\text { from } 2 \text { to } 5 \\
\mathrm{MPC}\end{array}$ & $\begin{array}{c}\text { from MPC } \\
\text { to } \mathrm{Cmax}\end{array}$ & $>5 \mathrm{MPC}$ & $>\mathrm{Cmax}$ \\
\hline $\begin{array}{l}\text { Extremely } \\
\text { dangerous }\end{array}$ & $>128$ & $>5 \mathrm{MPC}$ & $>$ Cmax & $>5 \mathrm{MPC}$ & $>\mathrm{Cmax}$ & & \\
\hline
\end{tabular}

\subsection{The results of soil research}

In the course of the research, 120 soil samples were collected in the catchment area. The analysis of the test results shows that in 13 samples there is an excess of the MPC value of arsenic, in one sample - of lead, in 18 samples - of zinc, in six samples - of copper, and in one sample - of nickel. In all samples, the integral pollution index does not exceed the standard value (16), the Zc varies from 1 to 11.7 , which corresponds to the permissible level of soil pollution. 


\section{Conclusion}

Based on the results of the interpretation of the laboratory data, it was found that in accordance with the Regional standard, the precipitation samples collected at stations 9, 10, $11,13,14,15,16,17$ are slightly polluted; at 4, 5, 18 - moderately polluted; at 1, 12, 19, 20, 21 - dangerously polluted. Bottom sediments with a concentration of pollutants that exceed the level requiring intervention are considered dangerously polluted. They belong to class IV.

As a result of soil testing, it was shown that the main pollutant of soils in the studied area is zinc, there is an excess of the MPC in 18 selected samples. The integral indicator of pollution does not exceed the standard value. The samples by the degree of chemical contamination, by the total indicator of pollution can be referred to the permissible category of pollution.

Further research may be related to the study of bottom sediments and soils at the full depth of the section, which will allow restoring the temporal dynamics of pollution and formulating scenarios for the development of environmental conditions.

\section{References}

1. B. Schütt, Geomorphology, 23(2-4), 273-283 (1998)

2. E. Sklyarov, Interpretation of Geochemical Data: Tutorial. Intermet Engineering, 288 (2001)

3. E. Nesterov, A. Timirgaleev, E. Maslova, News of Higher Educational Institutions. North Caucasus region. Natural sciences, 2, 96-99 (2008)

4. M. Postolova, E. Nesterov, N. Popkov, Issues of Regional Ecology, 5, 19 (2017)

5. M. Postolova, E. Nesterov, E. Mingareeva, Heavy Metals Content in Soils of Various Sampling Times. Geography: Science and Education Development. Collective monograph, 167-171 (2018)

6. E. Nesterov, P. Egorov, M. Markova, D. Morozov, International Multidisciplinary Scientific GeoConference Surveying Geology and Mining Ecology Management. Geochemical Indication of Bottom Sediments in the North-West of the East European Plain. SGEM, 19, 699-707 (2019)

7. S. Lebedev, M. Kulkova, L. Zarina, E. Nesterov, Assessment of Long-lived Radionuclides $(3 \mathrm{~h}, 14 \mathrm{c})$ and Heavy Metals in Snow Cover of Urban Areas as Indicators of Environmental Pollution (St. Petersburg, Russia). Processes and Phenomena on the Boundary Between Biogenic and Abiogenic Nature. Collection of papers presented at VI International Symposium, 297-313 (2020) 